Masculine Compromise 


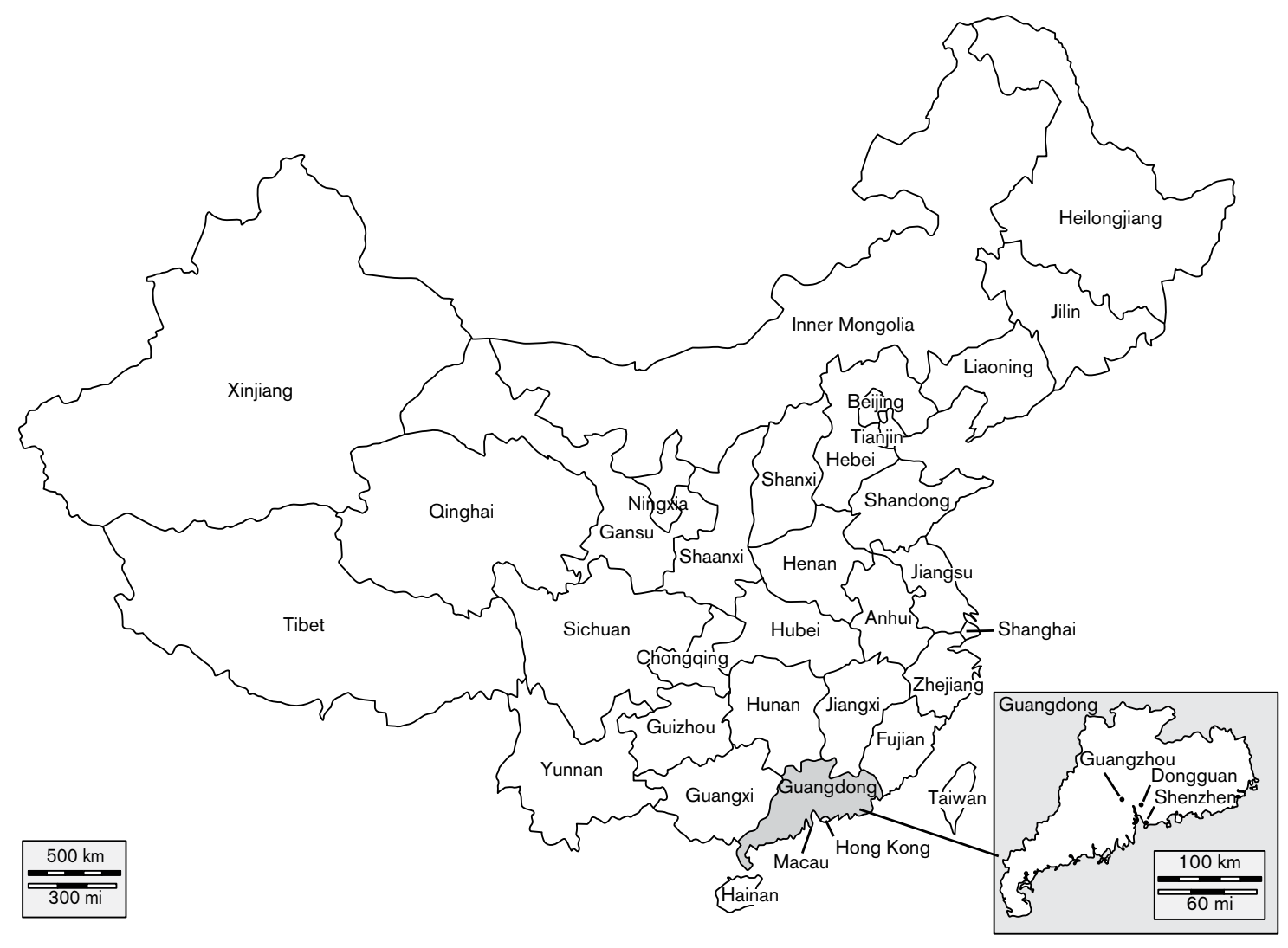




\section{Masculine Compromise}

Migration, Family, and Gender in China

\section{Susanne Y.P. Choi and Yinni Peng}

甲 
University of California Press, one of the most distinguished university presses in the United States, enriches lives around the world by advancing scholarship in the humanities, social sciences, and natural sciences. Its activities are supported by the UC Press Foundation and by philanthropic contributions from individuals and institutions. For more information, visit www.ucpress.edu.

University of California Press

Oakland, California

(C) 2016 by The Regents of the University of California

Library of Congress Cataloging-in-Publication Data

Choi, Susanne Y. P., author.

Masculine compromise : migration, family, and gender in China / Susanne Y. P. Choi and Yinni Peng.

pages $\mathrm{cm}$

Includes bibliographical references and index.

ISBN 978-0-520-28827-0 (cloth : alk. paper)

ISBN 978-0-520-28828-7 (pbk. : alk. paper)

ISBN 978-0-520-96325-2 (e-edition)

I. Rural-urban migration-China, South.

2. Urban-rural migration-China, South.

3. Masculinity_Family relationships_China, South.

4. Gender-China. 5. Migration, Internal-China,

South. 6. China-Social conditions-I949- I. Peng,

Yinni, author. II. Title.

HB2II4.A3 482016

$307.2^{\prime} 4095 \mathrm{I}-\mathrm{dc2} 3$

2015028009

Manufactured in the United States of America

$\begin{array}{llllllllll}24 & 23 & 22 & 2 \mathrm{I} & 20 & \text { I9 } & \text { I } 8 & \text { I7 } & \text { I6 } & \text { I5 }\end{array}$

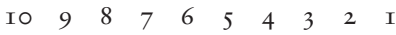

In keeping with a commitment to support environmentally responsible and sustainable printing practices, UC Press has printed this book on Natures Natural, a fiber that contains $30 \%$ post-consumer waste and meets the minimum requirements of ANSI/NISO Z39.48-I992 (R I997) (Permanence of Paper). 